\title{
Behavior of Six Okra, Abelmoschus esculentus (L.) Moench, Varieties as a Vegetable and as a Grain ${ }^{1}$
}

\author{
Francisco L. Jordän-Molero ${ }^{2}$
}

\begin{abstract}
Six okra varieties were compared as vegetable and as a grain. Varieties Emerald Green and Evergreen Velvet produced more tender pods per plant, but dehiscent varieties were heavier producers of dry pods both in number and weight per plant. Emerald Green and Evergreen Velvet produced longer but thinner fruits. Plant height and number of fruits decreased significantly when pods were harvested for grain. Dehiscent varielies were earlier producers and exhibited higher percentages of marketable fruit. On the basis of yields obtained, in this experiment, and on the basis of the ratio, $20 \%$ protein and $18 \%$, oil, okra can compare with several of the traditional oil crops of the tropics as a grain.
\end{abstract}

\section{INTRODUCTION}

Okra is mostly used as a vegetable, when the pod is immature green. In some countries green pods are dried and ground to be used as condiment. The nutritive value at this point is low when compared to that of okra seeds as a source of protein and oil. When used as a grain, okra seeds are similar to other oleaginous crops such as cotton, soybean and safflower. Protein and oil content are about 25 and $15 \%$, respectively, in dry okra seed.

Okra is an important vegetable in Africa, Asia, tropical America and the southern United States. Several varieties have originated in Louisiana, or through the Campbell Soup Co. in Riverton, N.J. (6). In a report from the Philippine Islands (3) varieties Clemson Spineless and Emerald were high yielding. According to Mortensen et al. (7), varieties Clemson and Perkin's Spineless adapt well in the tropics. Winters (11) recommends White Velvet, Clemson and Perkin's Spineless for the Caribbean. In Puerto Rico, Childers et al. (1) reported White Velvet as better than Perkin's Long Green.

Kimbrough et al. (2) considered production of 12.5 tons of tender pods and 700 to $1,000 \mathrm{~kg}$ of seed per hectare as good yields. According to Purseglove (8), acceptable yields range between 3.5 and 5.6 tons of tender pods. Shoemaker (9) considered 3.4 tons for fresh market and 6.8 for processing as good yields in Georgia. Maximum seed yields ranging from a low of 1.2 to 4.0 tons per hectare were obtained in Puerto Rico with

\footnotetext{
${ }^{1}$ Manuscript submitted to Editorial Board January 31, 1985.

${ }^{2}$ Horticulturist, Department of Horticulture, College of Agricultural Sciences, University of Puerto Rico, Mayagüez, P.R. 00708.
} 
58,000 to 86,000 plants per hectare $(4,10)$. Martin (5) presents a list of typical yields of okra green pods ranging from 5.3 tons per hectare in India to 17.7 in the United States, and 2.1 tons of seeds in Brazil to 2.4 in the U.S. The potential for okra seems to be as an oil and protein crop. It is easy to cultivate and can be planted at any time of the year. However, most research on okra deals with the crop as a vegetable, with tender green pods.

\section{MATERIALS AND METHODS}

Okra varieties Clemson Spineless (CS), Perkin's Spineless (PS), Dwarf Green Long Pod (DGLP), White Velvet (WV), Emerald Green (EG) and Evergreen Velvet (EV) (the first three dehiscent; the others, nondehiscent), were compared in a randomized block design with three replications. There were 90 plants per experimental unit with a planting distance of $100 \mathrm{~cm}$ between rows and $45 \mathrm{~cm}$ within the row, equivalent to 22,000 plants per hectare. Soil was a Coto clay $\left(\mathrm{Cu} \mathrm{B}_{2}\right.$ II e3) with a $\mathrm{pH}$ of 7.6. Planting date was July 15, 1978. First picking for tender pods to be used as a vegetable was performed September 5 , with periodical pickings until the first of December. There were a total of 19 pickings for varieties C.S. and P.S.; 23 for D.G.L.P. and E.V.; and 25 pickings for E.G. and W.V. Final harvest for P.S. and C.S. was November 7; for E.V. and D.G.L.P., November 21; and for W.V. and E.G., December 1. There were four pickings of dry capsules to be used as grain: 10/17, 11/13, 11/21, and 12/ 1. Recorded data included number and weight of tender and dry pods, size of pods, height of plant, number of lateral branches, and yield of dry seeds.

\section{RESULTS AND DISCUSSION}

Okra plants harvested as a vegetable were taller than plants left to produce seed to be used as grain (differences were highly significant). White Velvet was the tallest variety, and Perkin's Spineless the smallest. Height ranged from 2.9 to $1.9 \mathrm{~m}$ as a vegetable and 2.7 to $1.4 \mathrm{~m}$ as grain. In both cases indehiscent varieties were taller than dehiscents.

Number of lateral branches per plant also presented significant differences among varieties but no difference was evident between fresh-pod plants and dry-pod plants (table 1).

The number of tender pods per plant to be used as vegetable showed wide differences among varieties and crop purpose (table 2). Differences between varieties when harvested for grain were not so pronounced. E.G. and E.V. produced 48 and 46 pods per plant, respectively. They were also the best yielders of dry pods, although the number of pods when gathered as grain was reduced to $46 \%$. Both varieties had more lateral branches and were among the tallest. Weight of pods per plant showed different 
results. Varieties CS and PS produced more than $1 \mathrm{~kg}$ of tender pods per plant. Both varieties are dehiscent and were the earliest producers; both required fewer pickings. After the first 10 pickings, PS had produced $55 \%$ of its crop; CS, $52 \%$; DGLP, $32 \%$; E.V, $29 \%$; EG, $28 \%$; and WV, $19 \%$. Production for varieties WV, EG, EV and DGLP peaked in picking number 15 (October 24); for CS, in picking number 11 (October 10), and for PS, picking number 9 (October 3 ).

Yield of dry pods and yield of dry seed per plant showed no difference

TABLE 1.-Height ( $m$ ) and number of lateral branches in okra

\begin{tabular}{lcccc}
\hline \multirow{2}{*}{ Variety } & \multicolumn{2}{c}{ Height $^{1}$} & \multicolumn{2}{c}{ Laterals $^{2}$} \\
& Vegetable & Grain & Vegetable & Grain \\
\hline WV & 2.97 & 2.66 & 1.4 & 1.4 \\
EG & 2.59 & 2.11 & 1.8 & 1.7 \\
CS & 1.89 & 1.45 & 1.2 & 1.1 \\
EV & 2.26 & 1.74 & 1.9 & 2.0 \\
DGLP & 2.10 & 1.69 & 1.7 & 1.7 \\
PS & 1.88 & 1.44 & 1.4 & 1.3 \\
\hline
\end{tabular}

${ }^{1}$ Significant at the .01 level.

${ }^{2}$ Significant at the .05 level.

'TabLe 2--Number, size and weight of tender pods per plant

\begin{tabular}{lccccc}
\hline Variety & $\begin{array}{c}\text { Tender } \\
\text { jods' }\end{array}$ & $\begin{array}{c}\text { Weight } \\
\text { per } \\
\text { plant }\end{array}$ & $\begin{array}{c}\text { Weight } \\
\text { of pod }\end{array}$ & $\begin{array}{c}\text { Pod } \\
\text { length }\end{array}$ & $\begin{array}{c}\text { Pod } \\
\text { diameter }\end{array}$ \\
\hline WV & $n o$. & $g$ & $g$ & $\mathrm{~cm}$ & $\mathrm{~cm}$ \\
EG & 31 & 669 & 21.6 & 12.2 & 1.8 \\
CS & 48 & 895 & 18.6 & 14.3 & 1.5 \\
EV & 35 & 1036 & 29.6 & 13.2 & 2.0 \\
DGLP & 46 & 838 & 19.3 & 14.3 & 1.4 \\
PS & 35 & 855 & 24.4 & 13.7 & 1.7 \\
\hline
\end{tabular}

${ }^{1}$ Significant at the .01 level.

among varieties (table 3). Fruits of dehiscent varieties were heavier, either tender or dry, probably because they were wider and thicker and have more seeds per capsule.

According to Mangual et al. (4) indehiscent varieties are better for seed production. They found significant differences in capsules per plot and weight of seed among varieties at different plant densities; Evergreen Velvet, Red Okra, Clemson Spineless and White Velvet.

Yield of dry pods ranged from 13 to $23 \%$ of the total weight when 
compared to pods harvested as a vegetable. Amount of seed represented a high of $54.9 \%$ of total weight of dry capsule in PS to a low of $48.4 \%$ in EV. On the basis of $20 \%$ for protein and $18 \%$ for oil, with a density of 22,000 plants per hectare, varieties EG and WV were the best producers. They produced an average of $380 \mathrm{~kg}$ of protein and $335 \mathrm{~kg}$ oil per hectare. This production makes okra similar to peanuts, sesame, and soybean in oil, and to all legumes, except soybean, in protein content. With higher plant densities (36-72 thousand plants per hectare), Mangual et al. (4) reported $612 \mathrm{~kg}$ of oil and $658 \mathrm{~kg}$ of protein in CS, and $289 \mathrm{~kg}$ of oil with $394 \mathrm{~kg}$ of protein in WV, a higher yield than that of many traditional legumes and oil seeds.

With okra as a vegetable, yields ranged from $14.7 \mathrm{t}$ in variety $\mathrm{WV}$ to $22.8 \mathrm{t}$ in CS, higher than those reported in the United States $(2,5,8,9)$.

It can be concluded from this experiment that the behavior of okra varieties differs according to crop purpose. As a vegetable, indehiscent

TABLE 3.-Data on dry capsules and seed

\begin{tabular}{lcccccc} 
Variety & Dry pods $^{1}$ & $\begin{array}{c}\text { Weight } \\
\text { per } \\
\text { plant }\end{array}$ & $\begin{array}{c}\text { Weight } \\
\text { of pod }\end{array}$ & $\begin{array}{c}\text { Pod } \\
\text { length }\end{array}$ & $\begin{array}{c}\text { Dry seeds } \\
\text { per plant }\end{array}$ & $\begin{array}{c}\text { Dry seeds } \\
\text { per } \\
\text { capsule }\end{array}$ \\
\hline & no. & $\boldsymbol{g}$ & $g$ & $\mathrm{~cm}$ & $\mathrm{~g}$ & $\mathrm{~g}$ \\
WV & 19 & 153 & 8.1 & 16.3 & 81.5 & 4.4 \\
EG & 23 & 179 & 7.8 & 22.2 & 92.6 & 4.0 \\
CS & 14 & $\mathbf{1 3 9}$ & 9.9 & 18.6 & 72.3 & 5.2 \\
EV & 20 & 153 & 7.6 & 25.6 & 72.8 & 3.7 \\
DGLP & 15 & 151 & 10.1 & 23.3 & $\mathbf{7 5 . 3}$ & 5.0 \\
PS & 14 & $\mathbf{1 3 8}$ & $\mathbf{9 . 9}$ & 19.2 & 74.9 & 5.4 \\
\hline
\end{tabular}

I Significant at the 01 level.

varieties such as Emerald Green and Evergreen Velvet produce more but lighter fruits than dehiscent varieties such as Clemson Spineless and Perkin's Spineless. As grain, indehiscent varieties produce significantly more fruits, but the statistical analysis did not show differences in weight of indehiscent dry pods or seeds, although in almost every case they topped those of dehiscent varieties.

\section{RESUMEN}

Seis variedades de quimbombó (Clemson Spineless, Perkins' Spineless, Dwarf Green Long Pod, White Velvet, Evergreen Velvet y Emeraid Green) se compararon a una densidad de 22,000 plantas por hectárea para determinar su comportamiento como hortaliza y como cápsula seca para usar la semilla como fuente de proteina y aceite. Los datos indican que, como hortaliza, las variedades indehiscentes Emerald Green y Evergreen Velvet superaron a las demás en número de frutas por planta mientras 
que las dehiscentes Clemson Spineless y Perkin's Spineless produjeron mayor peso por planta. Las variedades indehiscentes produjeron mayor número y peso de cápsulas secas por planta que las dehiscentes. Las cápsulas de las dehiscentes fueron más pesadas y produjeron más semillas por cápsula.

\section{LITERATURE CITED}

1. Childers, N. F., H. F. Winters, P. Seguinot-Robles and H. K. Plank, 1950. Vegetable Gardening in the Tropics, Fed. Exp. Stn. in P.R., USDA Circ. 32.

2. Kimbrough, W. D., L. J. Jones and J. F. Fontenot, 1977. Okra is produced primarily in the south as main dish vegetable, and for gumbos. In Gardening for Food and Fun. Yearb. Agric., USDA.

3. Madamba, C. P., C. G. Goseco, J. R. Deanon and G. B. Bantac, 1966. Yield responses of some vegetables and field crops to soil fumigation for the control of plant parasitic nematodes, Phil. Agric. 50: 804-16.

4. Mangual-Crespo, G. and F. W. Martin, 1980. Effect of spacing on seed, protein, and oil production of four okra varieties, J. Agric. Univ. P.R. 64 (4): 450-59.

5. Martin, F. W. and R. Ruberté, 1978. Vegetables for the hot, humid tropic. Part 2. Okra, Abelmoschus esculentus, SEA, USDA.

6. Minges P. A., 1972. Descriptive list of vegetable varieties. The American Seed Trade Association, Inc. and Am. Soc. Hort. Sci.

7. Mortensen, E. and T. Bullard, 1972. Handbook of Tropical and Subtropical Horticulture, AID, Department of State. Washington, D.C.

8. Purseglove, J. W., 1968. Tropical Crops, Dicotyledons 2., John Wiley and Sons, Inc. N.Y.

9. Shoemaker, J, S., 1953. Vegetable Growing, John Wiley and Sons. Inc. N.Y.

10. USDA Agric. Res., 1979. Striking oil with okra, 28 (1).

11. Winters, H. F. and G. W. Miskimen, 1967. Vegetable Gardening in the Caribbean Area, Handbk. 323, USDA. 